\title{
PENGELOLAAN DAN IMPLEMENTASI PROYEK SISTEM INFORMASI DALAM LINGKUP SDLC
}

\author{
Hari Bagus Mantik
}

hari.mantik@yahoo.com

\begin{abstract}
Meninjau sebuah proyek sistem informasi berarti mendalami seluruh komponen yang terdapat di dalamnya. Bagaimana struktur di bangun, metodelogi apa yang di gunakan, memahami karakteristik dalam suatu entitas proyek (internal dan external), pengelolaan sumber daya manusia, biaya (budgeting), dan waktu, hingga memastikan bagaimana proyek berhasil di eksekusi dan menghasilkan output (deliverable) sesuai dengan tujuan. Mengelola semиa ini bukan sebuah pekerjaan yang mudah, sejarah mengatakan bahwa banyak sekali -proyek besar ataupun kecil mengalami kegagalan. Tulisan ini memberikan perspektif bahwa mengelola proyek berarti tidak hanya memastikan struktur, SDM, dan budget tersedia, tapi juga melihat bagaimana menyelaraskan ketiga hal tersebut untuk meminimkan kegagalan suatu proyek.
\end{abstract}

\section{Pendahuluan}

Project Management, atau sering disebut dengan project management office (PMO) tumbuh pesat dalam lingkup suatu organisasi, terutama organisasi dengan skala menengah keatas, organisasi yang berbasis teknologi informasi, dan organisasi yang mengedepankan knowledgebased dalam pola kerja dan kultur mereka. PMO sangat dibutuhkan terutama bagi perusahaan yang menginginkan standard pelayanan yang baik, disiplin kerja, manajemen waktu, budgeting yang baik atau optimal, dan organisasi yang perlu pengelolaan sumberdaya manusia yang cukup kompleks (berbeda latar belakang ataupun karakteristik).

PMO yang dipimpin oleh seorang project manager (PM) mempunyai struktur yang berbeda dengan struktur organisasi biasa. Struktur mereka lebih dikenal dengan struktur matrix, dimana terdapat cross-functional line atau hubungan lintas departemen yang melatar belakangi kondisi kerja mereka.

PMO banyak digunakan diantaranya mulai dari kegiatan atau aktivitas pekerjaan arsitekur dan sipil, event organizer, aktivitas pemasaran, hingga perancangan proyek sistem informasi.

\section{Proyek sistem informasi}

Apakah project management, dan apa yang membedakannya dengan proyek sistem informasi? Project management menurut olson adalah suatu aktivitas yang baru, unik, dan kompleks yang harus diselesaikan. Olson memberi contoh diantaranya adalah aktivitas menyeberangkan patung liberti melalui samudra atlantik adalah sesuatu yang unik, baru dan kompleks.

Project management juga merupakan suatu aktivitas yang mempunyai tujuan yang pasti, dan terdiri dari anggota yang 
datang dari berbagai macam latar belakang yang berbeda (cut across organization lines). Kondisi ini membuat memimpin suatu proyek adalah pekerjaan yang tidak mudah.

Lalu bagaimana dengan proyek sistem informasi? Secara menyeluruh sifat dan karakteristiknya adalah sama dengan project management (baru, unik, anggota dengan latar belakang berbeda, dan mempunyai tujuan pasti). Akan tetapi proyek sistem informasi tidaklah selalu unik, banyak yang bersifat customize dan berkembang menjadi proyek baru. Proyek system informasi biasanya berdasakan salah satu metodologi (SDLC) yang sifatnya generik. Baik metodologi waterfall (pengembangan dari atas ke bawah) ataupun menggunakan Agile methodology (pengembangan cepat build-develop-test)

\section{Karakteristik proyek sistem informasi}

Proyek sistem informasi mempu-

nyai beberapa karakteristik seperti di bawah ini:

- Pertama, proyek sistem informasi terkait dengan uncertainty and risk. Sesuatu yang dilakukan untuk pertama kali, dan dengan melibatkan sumber daya yang bervarian tentu mengakibatkan project sangat beresiko dan mempunyai derajat ketidakpastian yang tinggi.

- Kedua, proyek sistem informasi sering dan biasanya terlambat atau melewati batas waktu. Karena project merupakan satu koleksi aktivitas yang mempunyai fase dan milestone/pencapaian, satu fase yang terlambat akan menyebabkan fase berikutnya secara paralel akan terlambat. Akan tetapi jika satu fase dikerjakan lebih cepat, fase berikutnya tetap harus mengikuti jadwal yang telah ditetapkan. Artinya suatu project sering terlambat, tetapi jarang sekali project selesai lebih cepat dari waktu yang ditetapkan.

- Ketiga, project sarat dengan derajat konflik yang tinggi. Beragam latar belakang dan beragam keahlian akan membuat pengambilan keputusan akan lebih sulit dari organisasi non-project.

- Keempat, project mempunyai ukuran (size) tergantung pada tingkat kompleksitas pekerjaan. Mulai dari ukuran individul (misal pembuatan program atau koding sederhana), ukuran organisasi (yang melibatkan dua organisasi atau lebih plus keterlibatan third party), hingga ukuran multiorganisasi atau multi nasional (suatu project yang melibatkan beberapa negara. Misal, proyek NASA atau pesawat ulang alik yang dikerjakan oleh lebih dari 2 negara)

\section{Entitas dari project}

Suatu project terdiri dari orangorang yang berkompeten di dalamnya.

Entitas pertama adalah project manager (PM). Seorang PM bertanggung jawab pada tiga hal penting, yaitu koordinasi, budgeting atau pembiayaan, dan integrated planning atau perencanaan menyeluruh. Koordinasi oleh PM adalah termasuk koordinasi ke dalam entitas untuk seluruh anggota dan koordinasi di luar entitas termasuk klien, third party dan pemerintah. Koordinasi merupakan kompetensi utama dari seorang PM mengingat tingkat koflik yang tinggi dalam suatu proyek sehingga fungsi PM sebagai liaison 
dan engagement mempunyai peranan yang sangat kritis.

Entitas kedua dalam proyek sistem informasi adalah tim proyek. Tim ini biasanya terdiri dari anggota yang berperan penting dalam metodologi waterfall. Business analyst dan system analyst (bertugas melakukan identifikasi kebutuhan bisnis dan sistem dalam suatu proyek). Programmer (melakukan koding atau mentransformasi kebutuhan bisnis menjadi aplikasi). Quality assurance atau tester (menjamin aplikasi yang dibuat sesuai dengan standard qualitas sistem informasi). Tim Operation dan system administrator (bertanggungjawab terhadap implementasi, migrasi sistem, dan kehandalan database). Tim Operation dan support (memastikan bahwa sistem berada dalam kestabilan yang baik selama masa integrasi dalam periode waktu tertentu).

Entitas ketiga adalah Project Management System (tools atau sistem informasi yang memberikan informasi dan membantu aktivitas proyek). Tools dalam project sangat dibutuhkan untuk membantu PM berkoordinasi secara cepat dan efektif dengan tim nya. Selain tools dari microsoft project management yang merupakan alat bantu PM dalam melihat aktifitas seharihari, banyak organisasi menggunakan tools lainnya seperti redmine atau jira untuk mempermudah koordinasi dengan tim lainya.

\section{Struktur organisasi berbasis project}

Kita mengenal beberapa jenis struktur organisasi. Struktur organisasi fungsional, struktur organisasi produk, struktur organisasi hybrid, struktur project, dan struktur matrix. Menurut olson struktur yang terdekat dan cocok dengan organisasi proyek adalah struktur project, dan struktur matrix.

Struktur project ditandai dengan adanya pemisahan dan independensi dari fungsi fungsi yang ada. Struktur project juga kadang disebut dengan stand-alone organization karena menjelaskan tujuan yang spesifik dari tiap entitas, Berikut contoh struktur organisasi project:

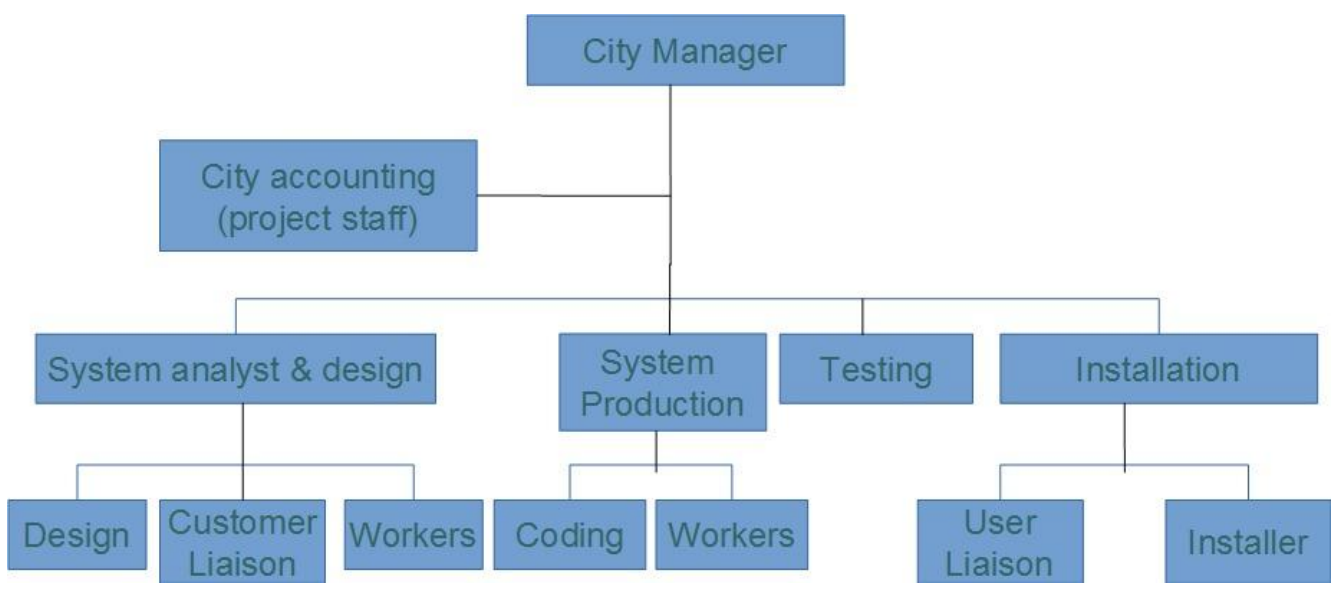

Gambar 1: Struktur organisasi project (David L. Olson) 
Sedangkan struktur matrix mencerminkan struktur dimana pelaporan, tanggungjawab dan otoritasnya mengalami overlay, dan terdapat perpaduan rentang kendali baik secara vertikal dan horisontal. Artinya wewenang di delegasikan baik ke atas dan ke bawah. Struktur ini mempunyai kelebihan diantaranya lebih mengoptimal- kan sumber daya dengan kompetensi yang sesuai secara optimal dan fleksibel, dan menumbuhkan integrasi dan koordinasi yang lebih kohesif. Hal ini tentu sangat cocok untuk suatu organisasi yang berbasis project, dimana masalah konflik, waktu, wewenang, dan koordinasi paling sering menjadi isu. Berikut contoh struktur matrix.

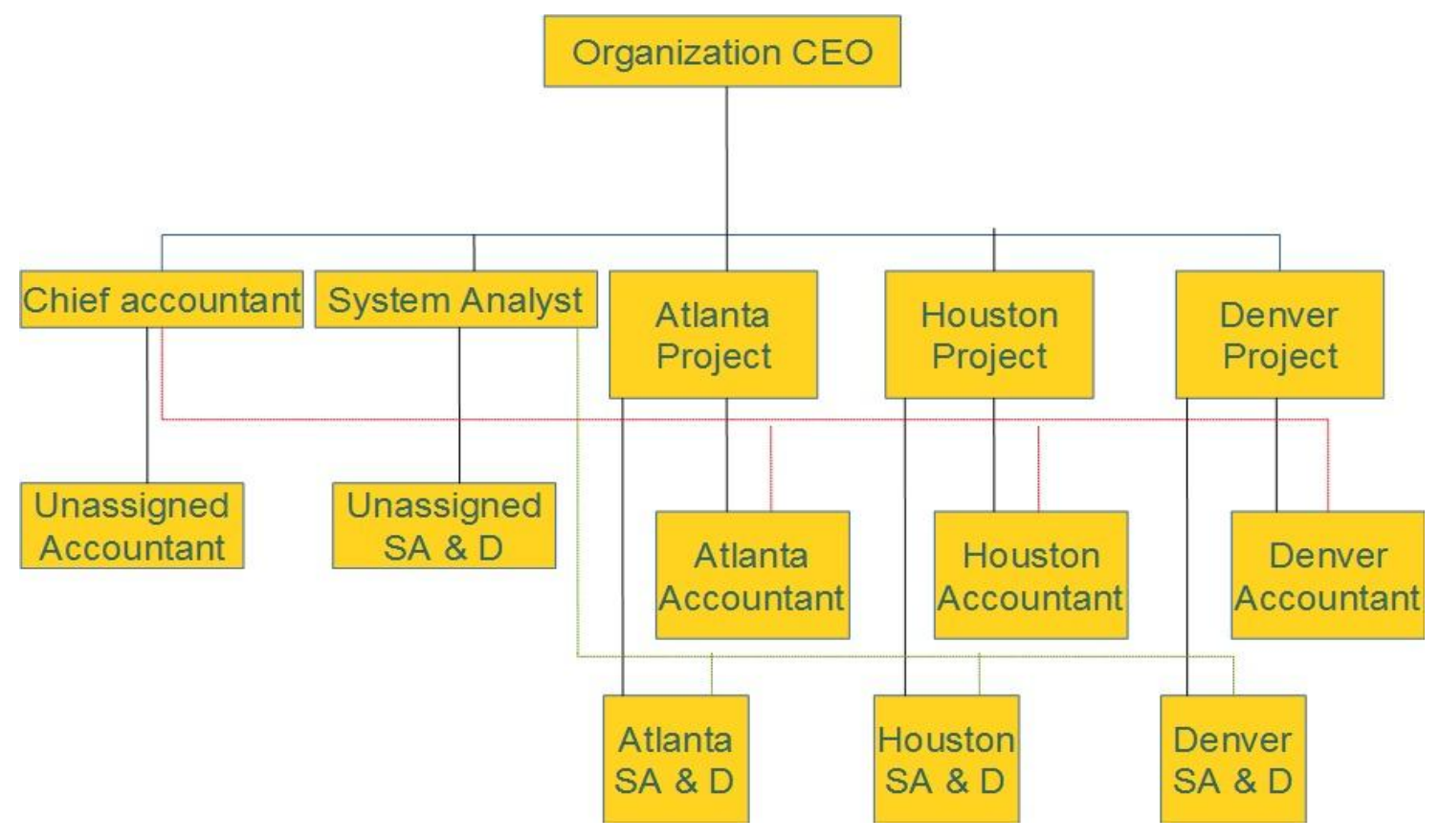

Gambar 2: struktur matrix (David L. Olson)

\section{Project Charter}

Project charter adalah dokumen yang digunakan untuk memulai suatu project. Dokumen project charter berisi informasi penting yang mencakup penjelasan ringkas dari sebuah proyek yang sedang dikerjakan, latar belakang dijalankannya proyek, deskripsi, target, ruang lingkup, tim yang terlibat, durasi pengerjaan proyek, dan sebagainya.

Project charter berfungsi memberkan arahan dan fokus yang jelas kepada tim mengenai sasaran yang ingin dicapai dari sebuah project. Dokumen ini juga akan menyelaraskan antara tujuan dari pelaksanaan proyek dengan tujuan dari bisnis organisasi skala yang lebih besar.

Input atau dasar dari project charter biasanya berisikan:

1. SOW (statement of work): Merupakan deskripsi jelas dari suatu proyek 
2. Business case: Berupa informasi tambahan sebagai wacana dalam sebuah proyek

3. Agreements/MOU/SLA: Berisi dokumen kesepakatan dengan user

4. Enterprise environmental factors: Beberapa standar atau regulasi yang harus dipatuhi

5. Organizational process assets: Berupa knowledge based atau lesson learned

\section{Project Selection and Approval (Pe- milihan Investasi Proyek)}

Project selection merupakan suatu proses penilaian dan seleksi atas suatu proyek yang akan di bangun berdasarkan beberapa sisi seperti kriteria, prioritas, budget, dan lainnya. Beberapa dasar dari seleksi proyek ini dilihat dari 2 (dua) alat ukur, yaitu:

1. Intangible factors, atau aset yang tidak berwujud, seperti paten dan hak cipta. Mayoritas perusahaan mengambil faktor intangible dalam proyek mereka sebagai sesuatu yang dapat meningkatkan citra di mata pesaing atau pelanggan.
2. Tangible factor, atau aset yang terlihat. Faktor ini jelas dapat diukur secara nyata karena mempunyai outcome dan benefit bagi perusahaan.

Pemilihan proyek secara matematis sederhana dapat di ukur melalui rumus net present value. Artinya, apakah nilai suatu proyek saat ini akan sama jika dilihat secara mata uang di masa depan?

\section{Pemilihan investasi Proyek melalui perhitungan NPV (net present value)}

NPV merupakan selisih antara pemasukan dan pengeluaran yang telah didiskon dengan menggunakan social opportunity cost of capital sebagai faktor diskon, atau dengan kata lain "arus kas yang diperkirakan pada masa datang yang di dihitung dan di diskontokan saat ini". Menurut kasmir (2003:157) net present value (NPV) atau nilai bersih sekarang merupakan perbandingan antara PV kas bersih dengan PV investasi selama umur investasi.

Tabel NPV terhadap keputusan investasi

\begin{tabular}{|l|l|l|}
\hline NPV & Deskripsi & Keputusan investasi \\
\hline NPV $>0$ & Investasi memberikan manfaat & Proyek di jalankan \\
\hline NPV $<0$ & Investasi mengakibatkan kerugian & Proyek di tolak \\
\hline NPV = 0 & Investasi tidak meberikan untung atau rugi & $\begin{array}{l}\text { Dilaksanakan atau tidak, tidak akan ada dampak } \\
\text { bagi perusahaan. Strategi proyek harus di lihat } \\
\text { dari kriteria yang lain }\end{array}$ \\
\hline
\end{tabular}


Perhitungan Net present Value dan kasus sederhana pemilihan proyek

$\mathrm{PV}=\mathrm{FV} /(1+\mathrm{i})^{\wedge} \mathrm{n}$

$\mathrm{NPV}=\mathrm{PV}$ cash flow $-\mathrm{PV}$ investment

Dimana, PV adalah present value, FV adalah future value, i adalah faktor diskon, $\mathrm{n}$ adalah tahun.

\section{Berikut contoh sederhana pemilihan proyek (Kasus):}

Jika terdapat 2 pilihan proyek (proyek A dan proyek B), dengan investasi yang sama (masing-masing US\$ 100.000 untuk proyek A, dan B). Dengan diskon faktor $13 \%$ pertahun dan proyek diperkirakan selesai di tahun ke-4, yang mana seharusnya yang dipilih?

\begin{tabular}{|c|c|c|}
\hline Year $(\mathrm{n})$ & Cash Flow Proyek A & Cash Flow Proyek B \\
\hline 1 & 25000 & 50000 \\
\hline 2 & 40000 & 40000 \\
\hline 3 & 60000 & 35000 \\
\hline 4 & 75000 & 68000 \\
\hline
\end{tabular}

Proyek A

\begin{tabular}{|l|l|l|}
\hline Year $(\mathrm{n})$ & Cash flow & Present Value $(\mathrm{PV})$ \\
\hline 1 & 25000 & $25000 /(1+0,13)^{\wedge} 1=23.123,89$ \\
\hline 2 & 40000 & $40000 /(1+0,13)^{\wedge} 2=31.325,87$ \\
\hline 3 & 60000 & $60000 /(1+0,13)^{\wedge} 3=41.583,01$ \\
\hline 4 & 75000 & $75000 /(1+0,13)^{\wedge} 4=45.998,90$ \\
\hline Total & & $141.031,68$ \\
\hline
\end{tabular}

$\mathrm{NPV} /$ Net present value $\quad=\mathrm{PV}$ cashflow $-\mathrm{PV}$ investment

$=141.031,6-100.000$

$=41.031,68$

Proyek B

\begin{tabular}{|l|l|l|}
\hline Year $(\mathrm{n})$ & Cash flow & Present Value $(\mathrm{PV})$ \\
\hline 1 & 50000 & $50000 /(1+0,13)^{\wedge} 1=44.247,79$ \\
\hline 2 & 40000 & $40000 /(1+0,13)^{\wedge} 2=31.325,87$ \\
\hline 3 & 35000 & $35000 /(1+0,13)^{\wedge} 3=24.256,76$ \\
\hline 4 & 68000 & $68000 /(1+0,13)^{\wedge} 4=41.705,67$ \\
\hline Total & & $141.536,08$ \\
\hline
\end{tabular}


NPV / Net present value $\quad=$ PV cashflow $-\mathrm{PV}$ investment

$$
=141.536,08-100.000
$$$$
=41.536,08
$$

Kesimpulan: Pilih Proyek B dengan nilai NPV yang lebih tinggi

\section{Work Breakdown Structure dan Detailed task list}

Work Breakdown Structure (WBS)

adalah suatu metode pengorganisasian

proyek dalam bentuk hirarkis. WBS digunakan untuk memecah (breakdown) satu proses menjadi lebih terperinci agar memudahkan project manager dalam menjalankan proyek.

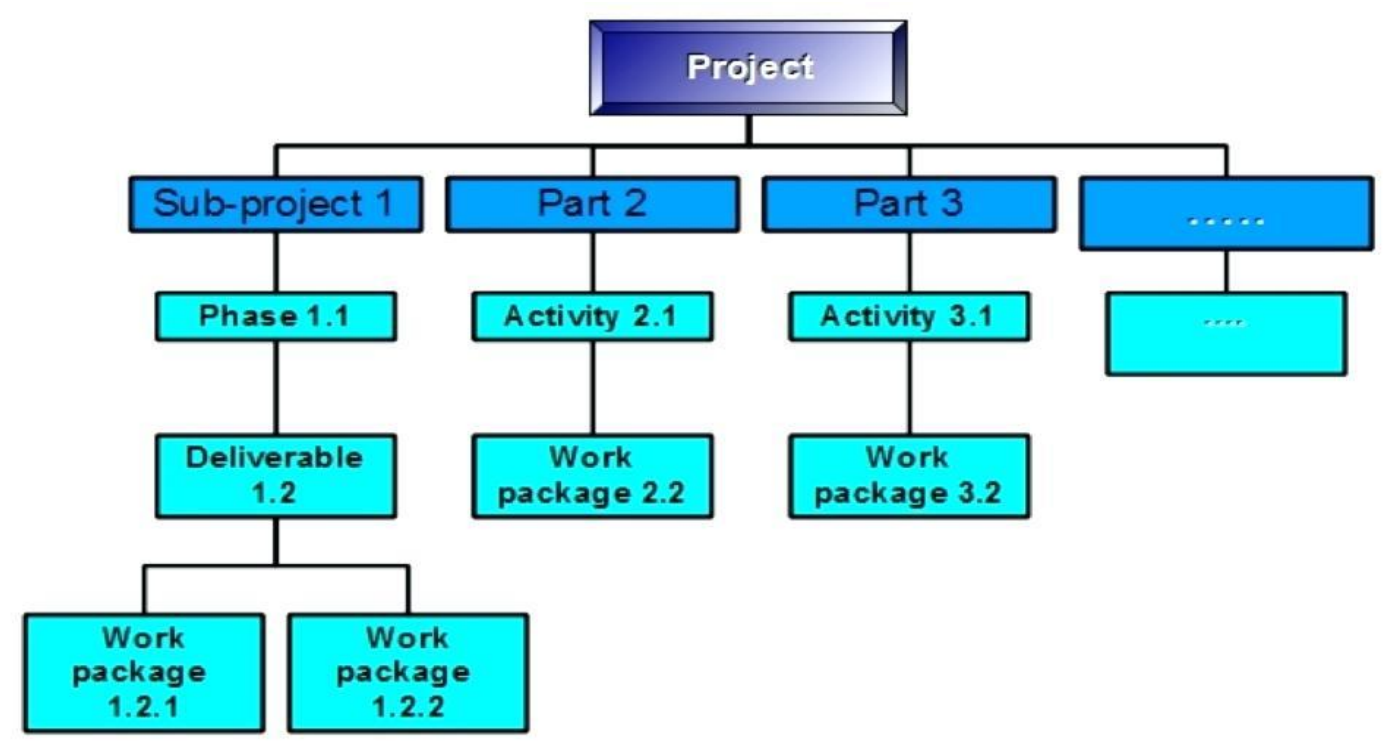

Gambar 3: Work Breakdown structure. Sumber (http://virtuart.me/wbs-tool)

WBS penting, karena kita dapat mengetahui estimasi, waktu, komponen dan fase-fase dari suatu proses.

Berikut adalah contoh dari WBS dengan Task:

"Install Decision Support System for Purchasing Manager"
Kita bisa memecah/breakdown proses tersebut menjadi:

Nama Task: Install Decision Support System for Purchasing Manager

Task A: System Design

Task B: HW and SW Acquisition

Task C: Installation 
Jika kita masih belum puas akan tingkat atomic/terkecil dari 3 task ini, kita bisa memecah lagi menjadi:

Task A: System Design

Subtask A.1: Define work process

Subtask A.2: Identify required information

Subtask A.3: Design software system

Subtask A.3.1: Basic

software

Subtask A.3.2: Data access

required

software required

Subtask A.3.3: Vendor

Subtask A.4: Identify hardware components

Task B: $H W$ and $S W$ Acquisition
Subtask B.1: Vendor HW quotation

Subtask B.2: Vendor SW quotation

Subtask B.2.1: Identify potential SW products

Subtask B.2.2: Obtain test copies

Subtask

B.2.3: $\quad$ User

comparison and approval

Task C: Installation

Subtask C.1: Order components

Subtask C.2: Test components

Subtask C.3: Assemble system

Subtask C.4: User test

Dari Task tersebut kita bisa gambarkan WBS nya seperti dibawah ini:

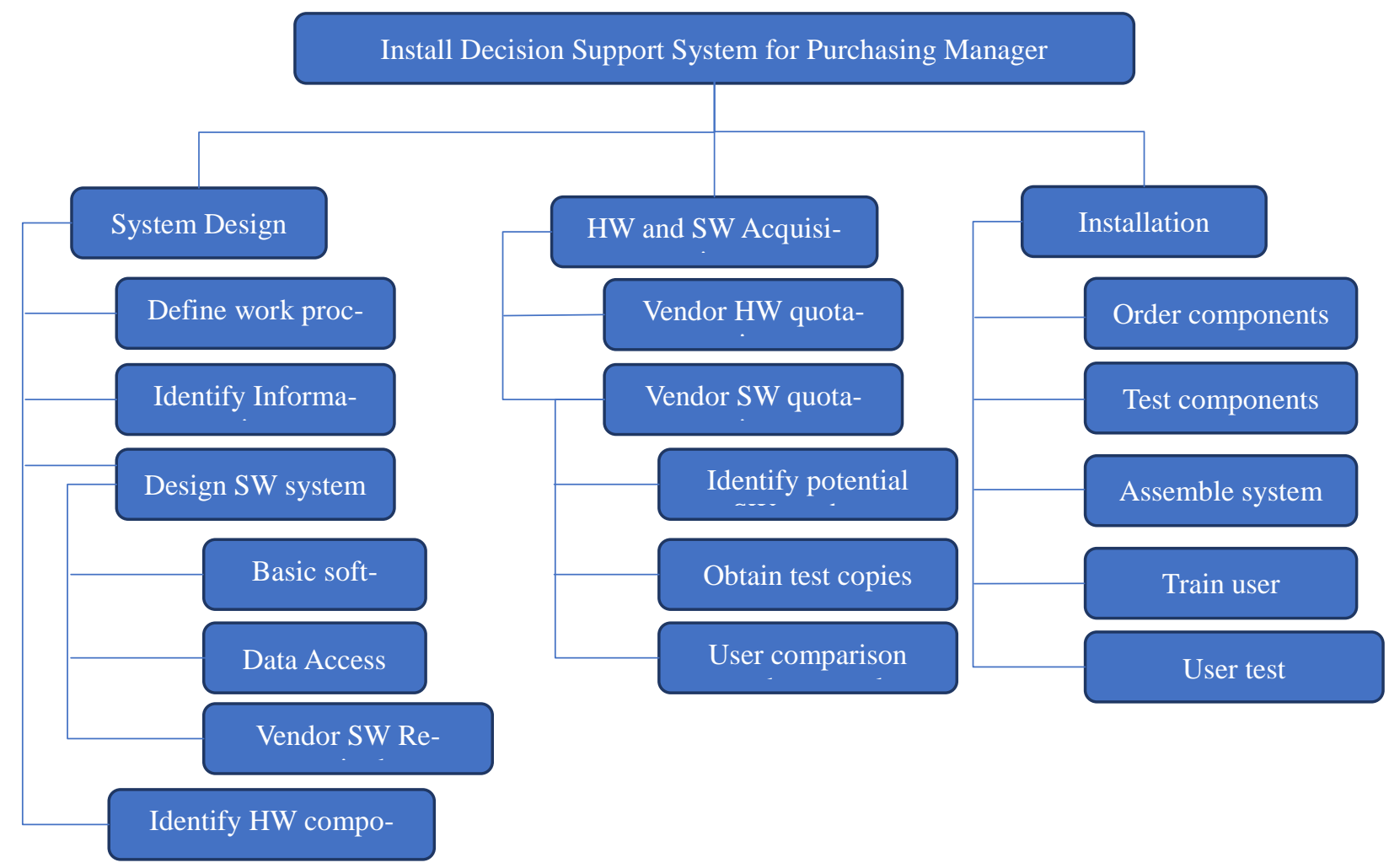

Gambar 4: Work Breakdown structure (David L Olson) 


\section{Detailed Task List}

Detailed task list (DTL) adalah satu kumpulan dan daftar (list) dari suatu pekerjaan, yang di deskripsikan sebagai sesuatu yang harus selesai (work to be done). DTL didalamnya termasuk informasi mengenai tugas dan tanggungjawab (assignment of responsibilities), predecessors, dan estimasi waktu. DTL biasanya berpasangan dengan diterbitkannya Work breakdown structure (WBS). Berikut adalah contoh DTL berdasarkan WBS sebelumnya.

Tabel 5: Detailed Task List (David L. Olson)

\begin{tabular}{|l|l|l|l|}
\hline Task & Subtask & $\begin{array}{l}\text { Responsible } \\
\text { Parties }\end{array}$ & Predecessors \\
\hline A & System Design & & \\
\hline A1 & Define work process & SE, User & None \\
\hline A2 & Identify required Information & SE, User & A2 \\
\hline A3 & Design software system & & \\
\hline A31 & Basic Software & SE & A2 \\
\hline A32 & Data Access Required & SE, User & A2 \\
\hline A33 & Vendor software required & SE, User & A2 \\
\hline A4 & Identify hardware components & SE, User & A31, A32, A33 \\
\hline A0 & System Design Milestone & & A4 \\
\hline B & HW and SW Acquisition & & \\
\hline B1 & Vendor HW quotation & HW Acquisition & A0 \\
\hline B2 & Vendor SW quotation & & \\
\hline B21 & Identify potential SW products & SW Acquisition & A0 \\
\hline B22 & Obtain test copies & SW Acquisition & B21 \\
\hline B23 & User comparison and approval & SE, User & B22 \\
\hline B0 & HW and SW Acquisition Milestone & & B1, B23 \\
\hline C & Installation & & \\
\hline C1 & Order components & SW Acquisition & B0 \\
\hline C2 & Test components & C1 \\
\hline C3 & Assemble system & SE \\
\hline C4 & Train user & SE & C3 \\
\hline C5 & User Test & SE, User & C4 \\
\hline C0 & Installation Milestone & \\
\hline & & & C5 \\
\hline
\end{tabular}

\section{Critical Path Analysis}

Critical Path Analysis (CPA) atau metode jalur kritis adalah suatu model kegiatan yang di gambarkan dalam bentuk jaringan dimana di dalamnya terdapat peristiwa yang menandakan awal dan akhir dari suatu proyek, seperti dalam gambar di bawah ini. 


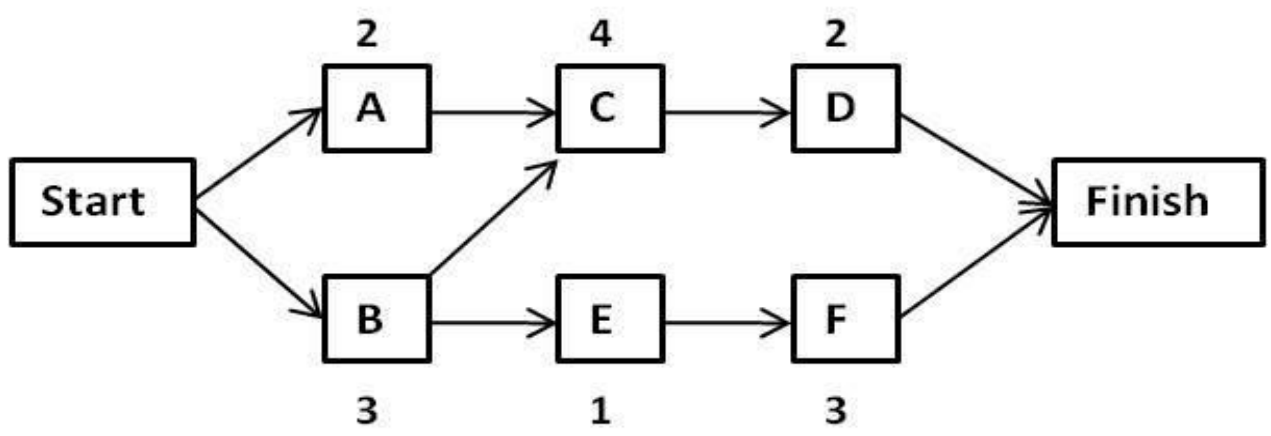

Gambar 6: Critical Path Analysis (https://josephzaarour.wordpress.com/2011/02/06/projectmanagement-critical-path-analysis/)

Early start schedule, Late start schedule, dan Slack

Di dalam CPA kita mengenal early start schedule dan late start schedule. Early start schedule merupakan waktu mulai paling awal dari satu kegiatan, terdiri dari early start (ES) dan early finish (EF). Late start schedule adalah waktu paling lambat kegiatan boleh dimulai tanpa memperlambat proyek, terdiri dari late finish (LF) dan late start (LS). Sedangkan slack adalah gap atau perbedaan antara early start schedule dengan late start schedule. Early start schedule dan Late start schedule terlihat seperti pada gambar berikut ini.

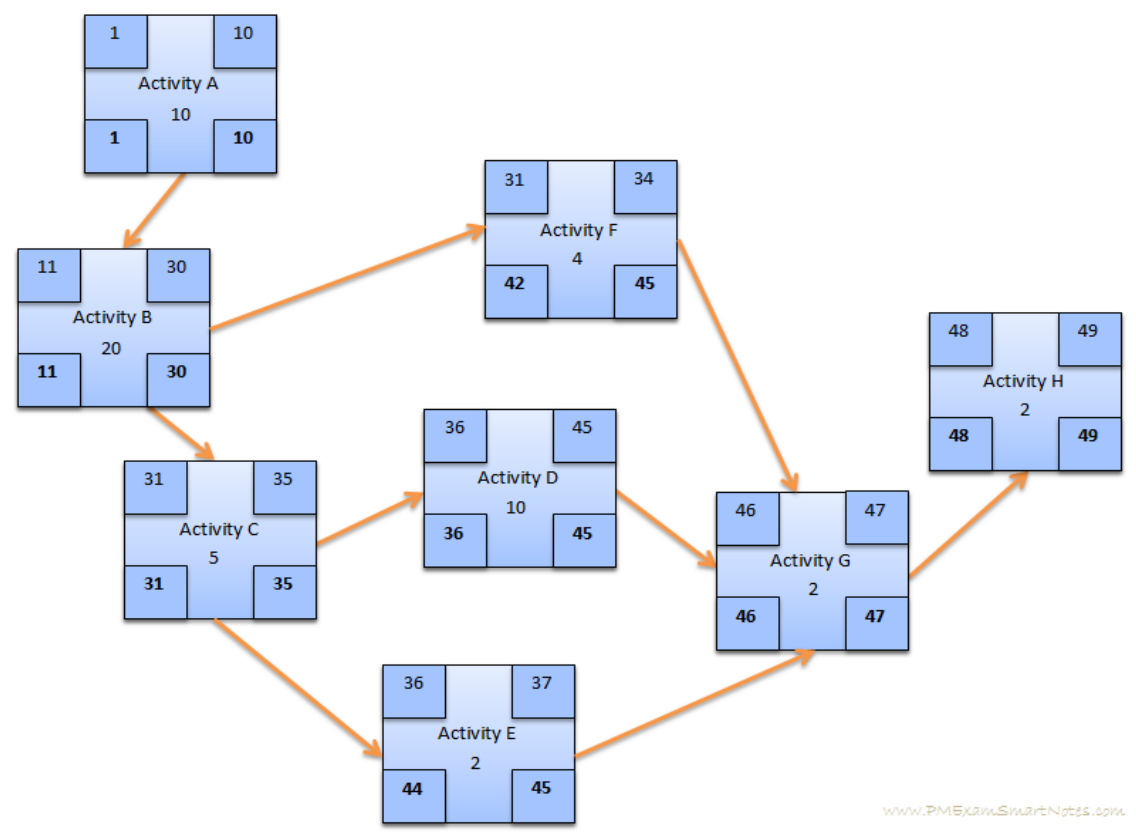

Gambar 7: Early start schedule, Late start schedule

(https://www.pmexamsmartnotes.com/how-to-calculate-critical-path-float-and-early-and-latestarts-and-finishes/3/) 
Kasus CPA

Kasus work breakdown structure di atas kita bisa jadikan sebagai contoh untuk pembuatan CPA. Selain itu berikut contoh lain pembuatan CPA, seperti table berikut:

\begin{tabular}{|l|l|l|}
\hline Activities & Duration (minggu) & Predecessors \\
\hline A. Estimate cost to complete project & 12 & None \\
\hline B. Bid Job and complete contract & 1 & A \\
\hline C. Build system & 40 & B \\
\hline D. Develop training & 20 & B \\
\hline E. Implement system & 5 & C,D \\
\hline
\end{tabular}

Results 1: Table Early Start Schedule

\begin{tabular}{|l|l|l|}
\hline Activities & Early Start $($ ES $)$ & Early Finish $(E F)$ \\
\hline A & 0 & 12 \\
\hline B & 12 & 13 \\
\hline C & 13 & 53 \\
\hline D & 13 & 33 \\
\hline E & Max $\{53,33\}$ & 58 \\
\hline
\end{tabular}

Results 2: Table Late Start Schedule

\begin{tabular}{|l|l|l|}
\hline Activities & Late Finish $($ LF $)$ & Late Start $($ LS $)$ \\
\hline E & 58 & 53 \\
\hline D & 53 & 33 \\
\hline C & 53 & 13 \\
\hline B & Min $\{53,13\}$ & 12 \\
\hline A & 12 & 0 \\
\hline
\end{tabular}

Result 3: Table Slack

\begin{tabular}{|l|c|c|c|c|c|l|}
\hline Activities & ES & $E F$ & $L S$ & $L F$ & Slack & Results \\
\hline A & 0 & 12 & 0 & 12 & 0 & Critical \\
\hline B & 12 & 13 & 12 & 13 & 0 & Critical \\
\hline C & 13 & 53 & 13 & 53 & 0 & Critical \\
\hline D & 13 & 33 & 33 & 53 & 20 & SLACK \\
\hline E & 53 & 58 & 53 & 58 & 0 & Critical \\
\hline
\end{tabular}




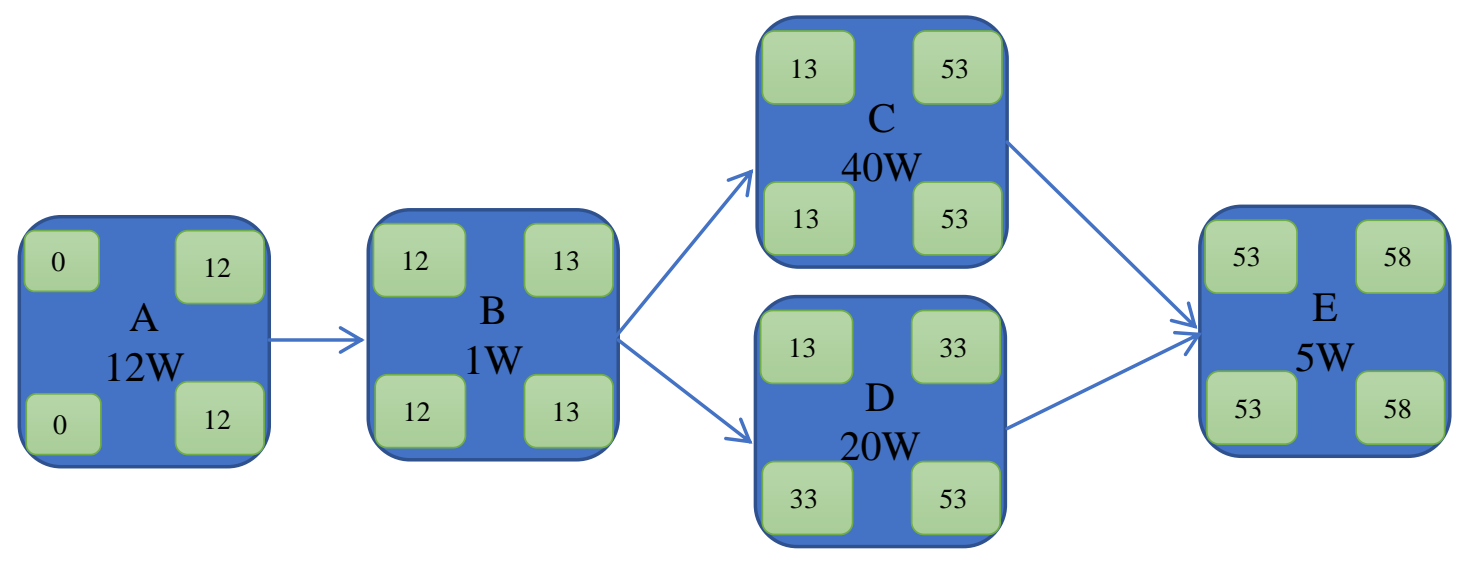

\section{Project implementation}

Project implementation atau project execution adalah suatu keadaan dimana visi dan rencana proyek akan menjadi kenyataan. Seluruh kesimpulan, setelah melalui tahapan evaluasi, pengambilan keputusan, pernyataan misi, perencanaan, dan budgeting akan ditentukan (go live) di fase project implementation. Implementasi bisa menjadi gagal atau berhasil sangat tergantung bagaimana seorang Project Manager berserta stakeholders di dalamnya menjalankan kegiatan proyek sesuai amanah visi-misi-dan-perencanaan.

\section{Information Systems Project failure}

Kegagalan suatu proyek sering terjadi karena dua hal, yaitu: technical validity dan organizational validity. Sistem da-pat dianggap valid secara teknis (technical validity), namun karena sesuatu dan lain hal user tidak mau dan tidak suka menggunakan sistem tersebut (organizational validity). Dalam bukunya, olson menengahkan beberapa kegagalan proyek berdasarkan technical dan organizational validity, yaitu:
1. Corresponding failure, merupakan kegagalan karena system tidak sesuai dengan obyektifnya, dimana coding yang dikerjakan oleh programmer tidak sesuai dengan yang diinginkan.

2. Process failure, adalah kegagalan saat proyek tidak berhasil diselesaikan secara tepat waktu. Secara teknis mungkin sesuai dengan obyektifnya, akan tetapi karena sesuatu atau lain hal (bisa karena masalah pembiayaan, ekonomis, dan lainnya), proyek berjalan dengan lambat.

3. Interaction and expectation failure, terjadi saat sistem secara teknis berhasil, juga secara waktu sesuai dengan rencana. Tapi users tidak mau menggunakannya oleh karena secara bisnis ternyata system tidak memberikan dampak dan solusi apapun bagi pengguna ataupun bagi pasar.

\section{Kesimpulan / penutup}

Proyek system informasi tidak selamanya gagal, dan tidak juga selalu berhasil. Menurut Olson, dalam bukunya, Information System Project Management, 
"successful implementation has been found to require mastery of the technical aspects of the systems along with understanding of key organizational and behavioral dynamics". - Suksesnya implementasi suatu proyek tidak hanya dilihat dari penguasaan SDM terhadap aspek teknis, akan tetapi juga dilihat dari bagaimana penguasaan teknis tersebut berjalan beriringan dengan pemahaman terhadap unsur-unsur utama yang terkandung dalam organisasi serta perilaku pelaku bisnis itu sendiri. Proyek system informasi juga adalah suatu pekerjaan Bersama (teamwork), suatu sinkronisasi manusia dengan perbagai perilakunya, bagaimana komitmen seluruh pihak dalam menjalankan aktivitas sesuai waktu, biaya, serta memahami cara pandang dan menyamakan persepsi pada satu paradigma agar tercapai tujuan tujuan proyek.

\section{Referensi:}

Olson, David L, Information System Project Management, McGraw Hill, 2003

Kasmir, Bank Dan Lembaga Keuangan lainnya. Jakarta: PT Raja Grafindo Persada. 2003

Hatch, Mary Jo, Organization Theory, Oxford University Press, 1997

www.redmine.org, 2018

www.atlassian.com/jira, 2018

www.shiftindonesia.com/project-charterpenentu-keberhasilan-dan-kegagalanproyek, 2018 